\title{
Pits in the optic disc associated with macular degeneration
}

\author{
R. GORDON AND R. K. GHATFIELD \\ Tennent Institute of Ophthalmology, Western Infirmary, Glasgow
}

Wiethe (1882) first described congenital pits or holes in the optic disc and since then cases have been frequently reported. Reis (1908) estimated the frequency of the anomaly to be as high as one case in every I I, 00o ophthalmic patients. The condition may be discovered incidentally in an otherwise normal eye. Many cases, however, are brought to notice because of an associated lesion in the macular area. The macular abnormalities detected have varied from a picture of central serous retinopathy, macular oedema, macular cyst, or macular haemorrhage to simple pigmentary deposits.

Kranenburg (1960) reviewed the world literature and added 24 cases of pits in the disc from the Amsterdam University Eye Clinic. He reported a characteristic picture of central serous retinopathy in 30 per cent. with remnants of that picture in 20 per cent. of cases. Sugar (1962) described six cases of pits in the optic disc, in two of which macular disturbance was present. He has since written further on the subject, giving an explanation for the associated macular pathology (Sugar, i964, i967). Greear (1942), Paufique and Etienne (1949), Wilson (1956), and Ferry (1963) have added valuable contributions.

A typical appearance (Fig. I) is that of a round or oval excavation close to the margin of the optic disc and with its long axis parallel to the margin. The majority of the pits are located in the inferior temporal quadrant of the disc and are usually single as well as

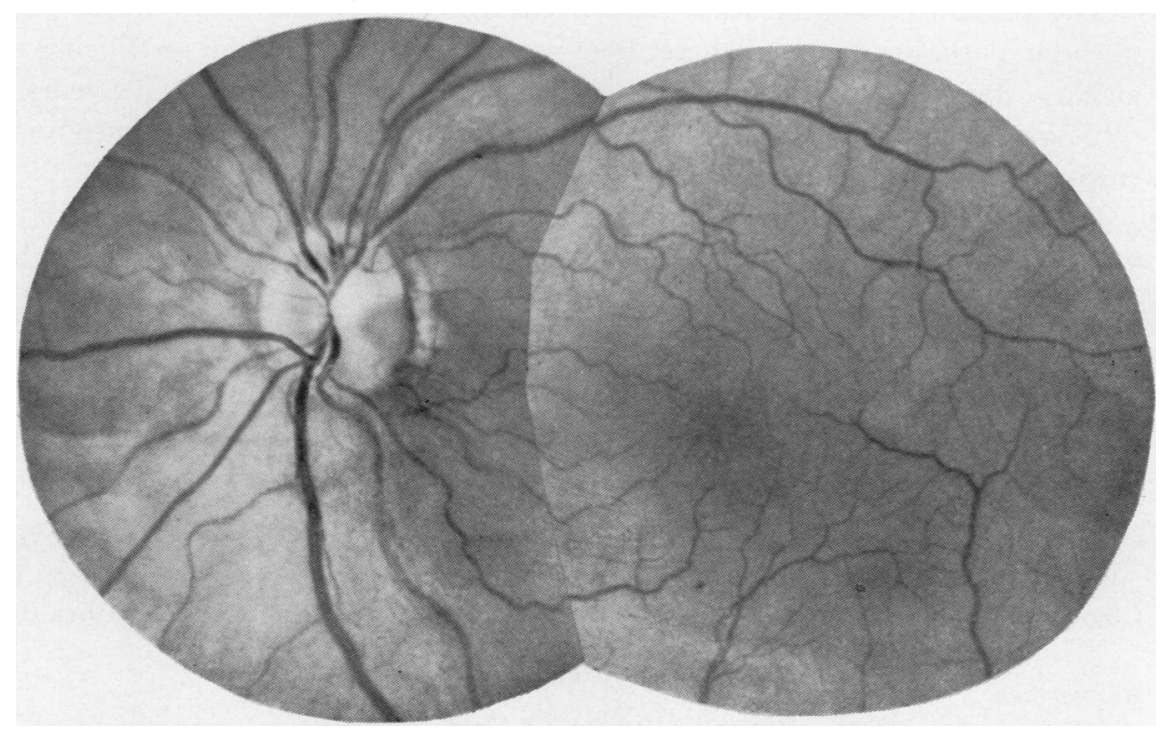

FIG. I Case 8 Left eye. Typical oval-shaped pit at temporal edge of optic disc. Fine radiate folds at macula 
unilateral. The anomaly, however, has been bilateral in ten reported cases (Sugar) The size of the pit may vary from one-eighth to one-quarter of the optic disc, witl the aperture pointing directly backwards, although it may be oblique. It often ha? a dark colour due to the presence of pigment or to shadows in the depth of the pit, whils biomicroscopy may reveal it to be filled with gossamer-like material (Wilson, $1956 \underset{\leftarrow}{\circ}$ Because of these factors, it can be difficult to estimate the depth but some may reach 8 mmo Henkind (1963) reported a pit $20 \mathrm{~mm}$. deep. The arrangement of the central retina vessels is often normal but occasionally a vessel passes towards the pit and disappears ir its depths to reappear on its other side. Opto-ciliary and cilio-retinal vessels have alsæ̋ been noted passing to and from the pit.

Histopathological examinations have been relatively few, but recently Ferry (1963 added seven cases to the eight previously reported in the literature (Lauber, I9o9; Coats $\omega$ I9o8; Seefelder, I915; Hagedoorn, I928; Calhoun, I930; Jaensch, I93 I ; Petersen, I958 $\frac{0}{0}$ These observations have shown that the pit is filled with rudimentary retinal tissue, asso ciated with glial elements, nerve fibres, and pigment epithelium. Indeed, the defect is of the nature of a pocket in the papilla filled with aberrant tissue rather than a true hole $\stackrel{t}{0}$ The condition has been considered by most observers to be an atypical coloboma with herniation of neuroectoderm into the nerve head at the margin of the optic disc. The frequency of an associated coloboma of the optic disc and of a minimal coloboma of the fundus gives support to this theory.

Coats (1908), however, suggested that the anomaly might be due to an abnorma $\overrightarrow{\mathscr{g}}$ metaplasia of a part of the optic disc stalk into retinal elements and pigment epithelium: Mann (1957), on the other hand, thought that some holes might be aberrations in Bergo meister's papilla.

In only three of the pathological reports (but not all commented on) was there arg associated macular lesion (Petersen, I958; Ferry, I963). The pits were on the tempora $\mathbb{B}$ side, two cases showing a serous detachment of the macula while the third showed markect oedema of the temporal retina, particularly in the outer plexiform layer.

The present communication reports twelve cases of pits in the optic disc. Eight hac macular pathology and, of these, four were of considerable interest, being observed from an early stage with macular oedema and followed-up over a period of 2 years. Fluoresceino retinography was found useful in the investigation of these patients and the method? employed was after that devised by Novotny and Alvis (r96r).

Visual field testing was performed in all cases, using a tangent screen at I metre. Biomicroscopy of the fundus was undertaken with a Goldmann fundus or Hruby lens.

\section{Case reports}

Details of the cases are given in the Table (opposite). A full history is given of Cases $\mathrm{I}, \mathbb{N}$ 2 , and 3 , as these are of particular interest, all being observed soon after the onset of the macular lesion.

Case I, a 28-year-old draughtsman with micropsia of the left eye, was referred to us by ang optician. This had been gradual in onset and first noticed 3 months before his attendance. Colours were duller with the left eye than the right. The patient's general health was excellent:?

\section{Examination}

The visual acuity was $6 / 5$ and $\mathrm{N}_{5}$ unaided in the right eye and $6 / 6$ and $\mathrm{N}_{5}$ unaided in the left. The right fundus was normal. The left disc (Fig. 2) showed a temporally-placed pit, having a fine over $\frac{\varrho}{0}$ lying membrane and adjacent to this a raised macular lesion, which was seen with the Goldmann 
Table

\begin{tabular}{|c|c|c|c|c|c|c|c|c|c|c|c|}
\hline $\begin{array}{l}\text { Case } \\
\text { No. }\end{array}$ & $\begin{array}{l}\text { Age } \\
(y r s)\end{array}$ & Sex & Eye & $\begin{array}{l}\text { Location } \\
\text { of hole }\end{array}$ & $\begin{array}{l}\text { Size (disc } \\
\text { diameters) }\end{array}$ & Appearance & $\begin{array}{c}\text { Colour } \\
\text { of pit }\end{array}$ & Vessels & Macula & Visual fields & $\begin{array}{l}\text { Visual } \\
\text { acuity }\end{array}$ \\
\hline $\mathbf{I}$ & 28 & $\mathbf{M}$ & $\mathbf{L}$ & $\begin{array}{l}\text { Mid- } \\
\text { temporal }\end{array}$ & $\mathrm{I} / 8$ & $\begin{array}{l}\text { Pit covered } \\
\text { by fine } \\
\text { membrane } \\
\text { Physiological } \\
\text { cupping }\end{array}$ & Brown & Nil & $\begin{array}{l}\text { Detachment } \\
\text { of pigment } \\
\text { epithelium }\end{array}$ & $\begin{array}{l}\text { Pericentral } \\
\text { scotoma }\end{array}$ & $6 / 6$ \\
\hline 2 & 20 & $\mathbf{F}$ & $\mathbf{L}$ & $\begin{array}{l}\text { Mid- } \\
\text { temporal }\end{array}$ & $1 / 6$ & $\begin{array}{l}\text { Partial } \\
\text { coloboma }\end{array}$ & $\begin{array}{l}\text { Greyish } \\
\text { brown }\end{array}$ & $\begin{array}{l}\text { Small } \\
\text { cilio-retinal } \\
\text { artery }\end{array}$ & $\begin{array}{l}\text { Shallow } \\
\text { detachment, } \\
\text { then pigmen- } \\
\text { tary clumping }\end{array}$ & $\begin{array}{l}\text { Centrocaecal } \\
\text { scotoma, later } \\
\text { enlarged } \\
\text { blind spot }\end{array}$ & $\begin{array}{l}1 / 60- \\
6 / 9\end{array}$ \\
\hline 3 & 43 & $\mathrm{~F}$ & $\mathbf{L}$ & $\begin{array}{l}\text { Mid- } \\
\text { temporal }\end{array}$ & $I / 5$ & $\begin{array}{l}\text { Physiological } \\
\text { cupping }\end{array}$ & $\begin{array}{l}\text { Dark } \\
\text { brown }\end{array}$ & $\begin{array}{l}\text { Opto-ciliary } \\
\text { vessel }\end{array}$ & $\begin{array}{l}\text { Shallow } \\
\text { detachment } \\
\text { with small } \\
\text { haemorrhages, } \\
\text { then pigmen- } \\
\text { tary clumping }\end{array}$ & $\begin{array}{l}\text { Pericentral } \\
\text { scotoma, later } \\
\text { centrocaecal } \\
\text { scotoma and } \\
\text { upper sector } \\
\text { defects }\end{array}$ & $\begin{array}{l}1 / 60- \\
3 / 60\end{array}$ \\
\hline 4 & 32 & $\mathbf{M}$ & $\mathbf{L}$ & $\begin{array}{l}\text { Infero- } \\
\text { temporal }\end{array}$ & $\mathrm{I} / 8$ & $\begin{array}{l}\text { Physiological } \\
\text { cupping }\end{array}$ & Brown & $\mathrm{Nil}$ & $\begin{array}{l}\text { Detachment, } \\
\text { then fine } \\
\text { pigmentary } \\
\text { stippling }\end{array}$ & $\begin{array}{l}\text { Arcuate } \\
\text { scotoma, small } \\
\text { pericentral } \\
\text { scotoma }\end{array}$ & $\begin{array}{l}6 / 60- \\
6 / 24\end{array}$ \\
\hline 5 & 45 & $\mathbf{F}$ & $\mathbf{R}$ & $\begin{array}{l}\text { Infero- } \\
\text { temporal }\end{array}$ & $1 / 8$ & $\begin{array}{l}\text { Deep } \\
\text { physiological } \\
\text { cupping }\end{array}$ & Grey & Nil & $\begin{array}{l}\text { Pigmentary } \\
\text { clumping } \\
\text { between disc } \\
\text { and macula }\end{array}$ & $\begin{array}{l}\text { Centrocaecal } \\
\text { scotoma }\end{array}$ & $6 / 9$ \\
\hline 6 & 18 & $\mathbf{F}$ & $\mathbf{R}$ & $\begin{array}{l}\text { Mid- } \\
\text { temporal }\end{array}$ & $1 / 5$ & $\begin{array}{l}\text { Partial } \\
\text { coloboma }\end{array}$ & Grey & $\mathrm{Nil}$ & $\begin{array}{l}\text { Pigmentary } \\
\text { changes }\end{array}$ & $\begin{array}{l}\text { Enlarged blind } \\
\text { spot, pericentral } \\
\text { scotoma }\end{array}$ & $6 / 36$ \\
\hline 7 & 74 & $\mathbf{F}$ & $\mathbf{L}$ & $\begin{array}{l}\text { Central } \\
\text { extending } \\
\text { to temporal } \\
\text { margin }\end{array}$ & $\mathbf{1} / 8$ & $\begin{array}{l}\text { Physiological } \\
\text { cupping }\end{array}$ & Grey & Nil & $\begin{array}{l}\text { Pigmentary } \\
\text { changes }\end{array}$ & $\begin{array}{l}\text { Arcuate } \\
\text { scotoma }\end{array}$ & $6 / 12$ \\
\hline 8 & 18 & $\mathbf{F}$ & $\mathbf{L}$ & $\begin{array}{l}\text { Mid- } \\
\text { temporal }\end{array}$ & $1 / 5$ & $\begin{array}{l}\text { Deep } \\
\text { physiological } \\
\text { cupping }\end{array}$ & $\begin{array}{l}\text { Greyish } \\
\text { brown }\end{array}$ & $\begin{array}{l}\text { Small } \\
\text { cilio-retinal } \\
\text { vessels } \\
\text { above and } \\
\text { below hole }\end{array}$ & $\begin{array}{l}\text { Fine radiate } \\
\text { folds }\end{array}$ & $\begin{array}{l}\text { Enlarged } \\
\text { blind spot }\end{array}$ & $6 / 6$ \\
\hline 9 & 50 & $\mathbf{F}$ & L & $\begin{array}{l}\text { Infero- } \\
\text { temporal }\end{array}$ & $1 / 8$ & $\begin{array}{l}\text { Deep } \\
\text { physiological } \\
\text { cupping }\end{array}$ & Brown & Nil & Nil & Nil & $6 / 6$ \\
\hline 10 & 23 & $\mathbf{F}$ & L & $\begin{array}{l}\text { Infero- } \\
\text { temporal } \\
\text { margin }\end{array}$ & $1 / 5$ & $\begin{array}{l}\text { Deep } \\
\text { physiological } \\
\text { cupping }\end{array}$ & Brown & $\mathrm{Nil}$ & Nil & $\begin{array}{l}\text { Enlarged } \\
\text { blind spot }\end{array}$ & $6 / 5$ \\
\hline II & 22 & $\mathbf{F}$ & Both & Temporal & $\begin{array}{l}\text { approx. } \\
1 / 4 \text { and } \\
1 / 5\end{array}$ & $\begin{array}{l}\text { Coloboma } \\
\text { of each disc }\end{array}$ & Brown & $\mathrm{Nil}$ & Nil & $\begin{array}{l}\text { Bilateral upper } \\
\text { sector defects } \\
\text { extending from } \\
\text { blind spot }\end{array}$ & $\begin{array}{l}6 / 5 \\
6 / 5\end{array}$ \\
\hline 12 & 71 & $\mathbf{F}$ & $\mathbf{R}$ & $\begin{array}{l}\text { Infero- } \\
\text { temporal }\end{array}$ & $\mathrm{I} / 8$ & $\begin{array}{l}\text { Physiological } \\
\text { cupping }\end{array}$ & Brown & $\begin{array}{l}\text { Large and } \\
\text { two smaller } \\
\text { cilio-retinal } \\
\text { arteries }\end{array}$ & Nil & Nil & $6 / 9$ \\
\hline
\end{tabular}

lens to be a detachment of the retinal pigment epithelium. A pericentral scotoma was revealed by visual field testing and fluorescein retinography was carried out at this time. This confirmed that the oedema was sited deep to the pigment epithelium and outlined exactly the area seen clinically (Fig. 3). It was also noted that there was laminar flow in the inferior temporal arteriole, the nearest main vessel to the optic nerve pit. The inferior aspect of the vessel was seen to fill with dye 2 seconds before the superior aspect or side nearer to the macular lesion (Fig. 3). Emptying of the arteriole took place in the same sequence, the inferior preceding the superior aspect; 5 minutes after injection the macular area was fading but, whereas the pit had been free of dye during the early phases, it was now fluorescing brightly (Fig. 4).

\section{Progress}

It was felt that treatment would not be of benefit and when he was seen 5 months later, the patient's symptoms were unchanged; the visual acuity was $6 / 9$ and $\mathrm{N}_{5}$ and the detachment of the pigment epithelium remained as before. 


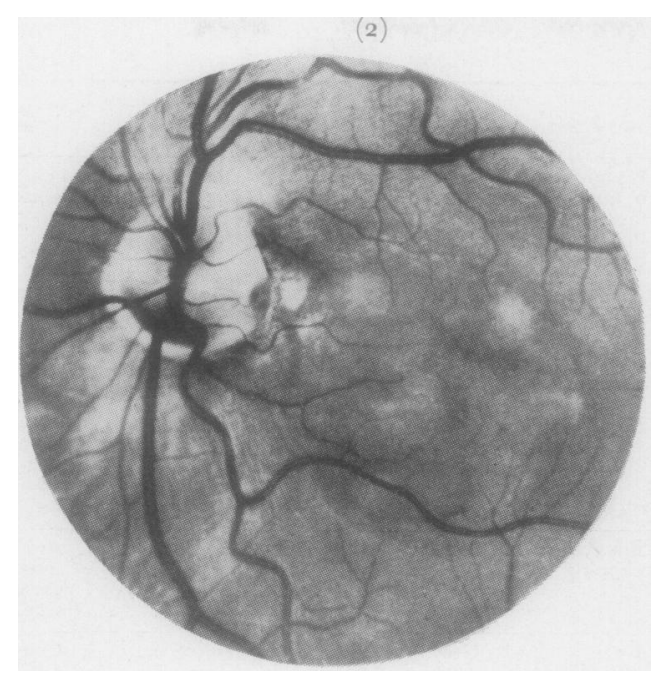

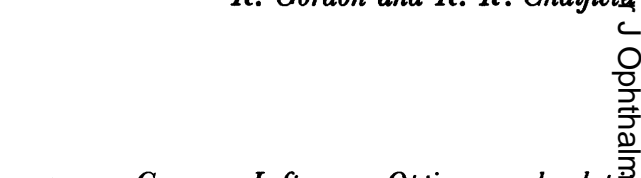
with contiguous detachment of retinal pigments. epithelium

FIG. 3 Case I Left eye. Fluorescein retino gram. Early arteriolar phase showing absence $\$$ fluorescein within pit, extent of detachment outline\% exactly by dye, and laminar flow in inferior temporat arteriole

FIG. 4 Case I Left eye. Late phase (3 minutes after injection); pit fluorescing brightly

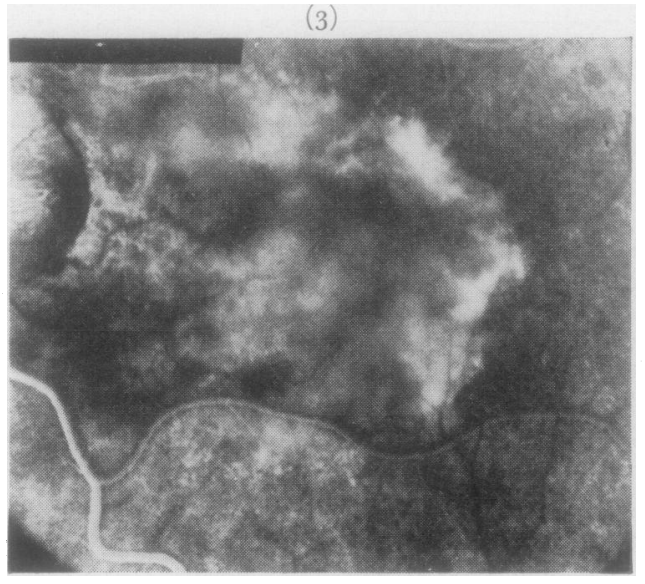

Case 2, a 20-year-old girl, complained of sudden loss of vision in the left eye. There was no oculari pain or headache and there had been no injury to the eye. The corrected visual acuity was $6 / 6$ in the right eye and $\mathrm{r} / 6 \mathrm{o}$ in the left.

\section{Examination}

There was a pit in the left optic disc on the temporal side; it was of a greyish-brown colour and wherr viewed through the Goldmann fundus lens the opening of the hole was seen to be directed backward心 and temporally. The optic disc had a large physiological cup amounting to a partial coloboma of the disc. There was a serous detachment of the macula (Fig. 5). An obvious channel of oedemat extended from the hole to below and beyond the macula. There was no posterior detachment of the vitreous, nor any adhesion between it and the retina. An examination of the visual fields showed a dense centro-caecal scotoma.

The other eye was perfectly normal although there was deep physiological cupping of the optice? nerve head.

The oedema cleared slowly, with the channel from the pit to the macula clearing first. Afte 6 weeks the visual acuity had improved to 6/24. There was continued slow improvement and $\frac{P}{D}$ after 6 months, vision had recovered to 6/9. The oedema had cleared and there was a fine macula? pigmentary disturbance. 


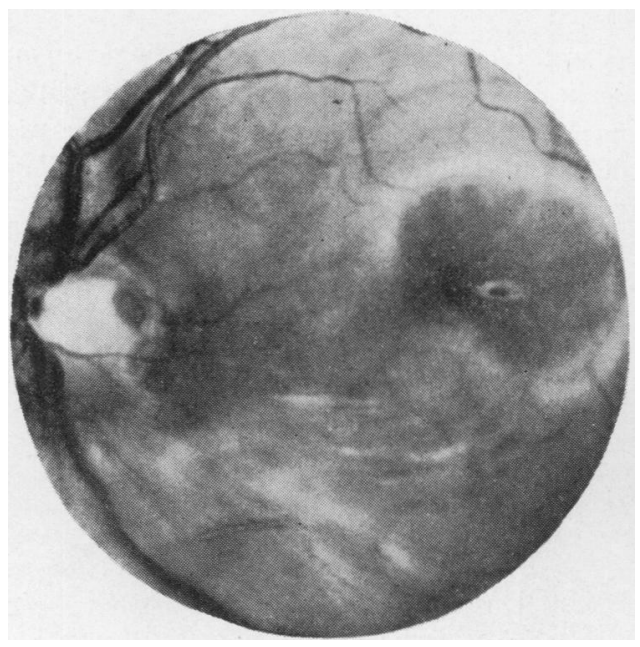

FIG. 5 Case 2 Left eye. Pit at temporal edge of optic nerve head. Shallow detachment of macula with channel of oedema extending from below pit to macula

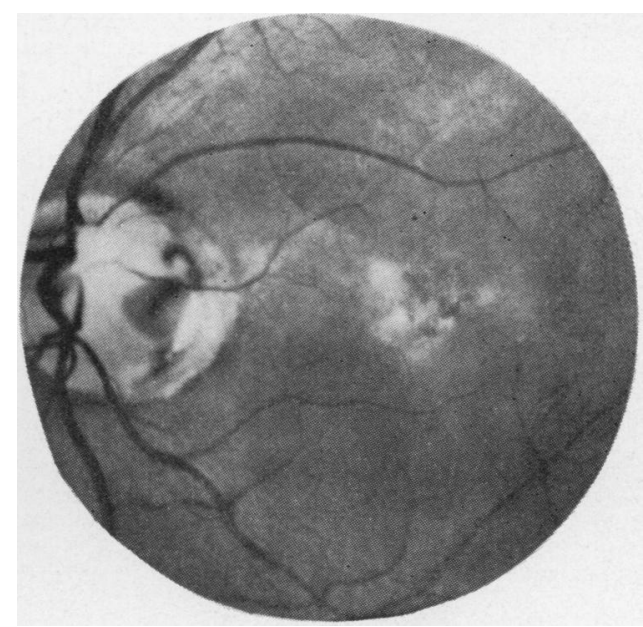

FIG. 6 Case 3 Left eye. Opto-ciliary vessel associated with temporally-placed pit in optic nerve head. Shallow serous detachment at macula and retinal pigmentary disturbance. Channel of oedema passes from pit to macula

Fluorescein retinography 2 days after the onset of symptoms, and again 4 months later when the oedema was still present, failed to show any defect in retinal pigment epithelium, except for a small area immediately adjacent to the pit, or seepage of dye into the neurosensory layer of the retina. There was no paramacular spot as seen in one type of central serous choroidopathy. Laminar blood flow was detected in the superior temporal retinal arteriole in a similar pattern to Case I with the side of the vessel away from the macular lesion filling first, followed 2 seconds later by the distal side. There was marked fluorescence within the pit itself, which did not appear until $2 \frac{1}{2}$ minutes after injection.

\section{Progress}

A further study 2 years later showed an identical picture at the disc and macula and the pit fluorescence was still present at 30 minutes but had disappeared by 60 minutes.

Case 3, a 43-year-old woman, had blurring of vision in the left eye for one month and was referred for an ophthalmologist's opinion.

\section{Examination}

The visual acuity was $6 / 6$ in the right eye and $\mathrm{r} / 6 \mathrm{o}$ in the left. The right eye was perfectly healthy. On the temporal margin of the left optic disc there was a pit, dark brown in colour and about 6 dioptres in depth. With the Goldmann lens it was seen to be filled with a fine meshwork of tissue and to be directed backwards and nasally. There was a deep physiological cup and choroidoretinal degeneration at the temporal edge of the disc. An opto-ciliary vessel was associated with the hole. There was oedema at the macula forming a serous detachment and a striking subretinal channel was seen passing from the optic disc at the upper aspect of the hole towards the macula (Fig. 6). This cleared slowly over a period of several weeks, beginning in the region of the channel, with the development of fine pigmentary clumping at the macula and also between it and the optic disc. During resolution, three small superficial haemorrhages appeared at the macula. 


\section{Progress}

After 5 months, the oedema had cleared and the macula showed gross degenerative changes. Th vision improved to $3 / 60$ only. Fluorescein retinography was carried out $2 \frac{1}{2}$ months after the onset of visual disturbance when the oedema had become localized to the macular area. There w䨚 choroidal "show-through" at the site of the sub-retinal channel and at the macula, although the was no evidence of seepage of dye (Fig. 7). There was fluorescein around but not in the hole but photographs beyond three minutes were not obtained.

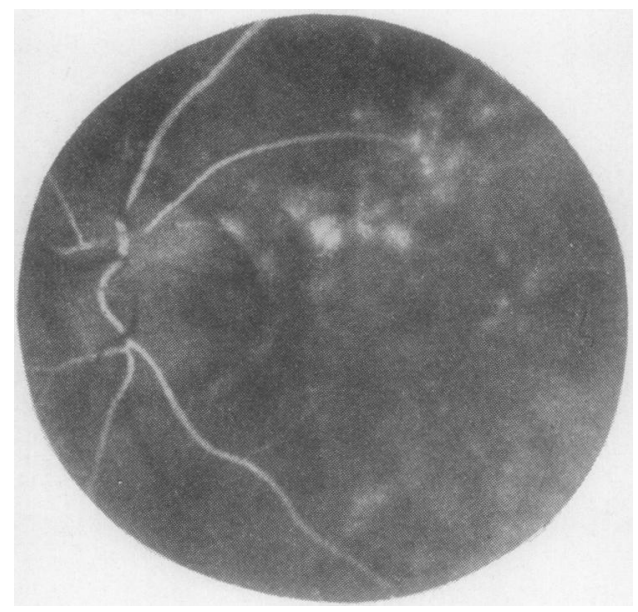

FIG. 7 Case 3 Left eye. Fluorescein retinogram (arteriolar phase). Choroidal "show-through" evi-i dent at site of sub-retinal channel from pit to macula $\rightarrow$

Case 4, a 32-year-old man, presented with sudden blurring of vision in his left eye. Oedema wâ present at the macula and a diagnosis of central serous choroidopathy had been made. The pot at the temporal margin of the disc had been overlooked at first. When the patient was examine 2 years after the incident, pigmentary changes were seen at the macula with the typical pit in th disc. Visual field testing revealed an enlarged blind spot with an arcuate scotoma. Visual acuit was at first 6/6o and improved to 6/24. Some of the defect of vision, however, was due to amblyopera associated with a convergent strabismus of the left eye. Fluorescein retinography could not carried out in this patient.

Cases 5, 6, and 7. These patients showed pigmentary degenerative changes at the macula of 8 varying degree but none was observed in an oedematous phase. In Case 5 , pigmentation was note in an arcuate fashion from the pit to the macula and this defect in the pigment epithelium w confirmed by revelation of the choroidal circulation on fluorescein studies, as in Case 3 .

Case 8. This patient showed an interesting appearance at the macula. There was an accentuatiof of the radiate folds formed by Henle's fibre layer, perhaps indicating a minimal degree of oedema in this layer (Fig. I). There was an absence of the foveal reflex. The visual acuity, however, was 6 , and the patient had no visual disturbance. The remaining cases revealed no abnormality in thg macular area.

Most cases showed some defect in the visual fields. These most typically took the form of an enlarged blind spot with or without an adjoining arcuate scotoma. In several $\overrightarrow{\text { of }}$ the cases, there was also a centrocaecal scotoma corresponding to the ophthalmoscopical $\bar{Q}$ observed lesion. In Case 2, with recovery of vision, an enlarged blind spot only remaine必 Case 3 , on the other hand, had a large central scotoma initially and later showed a centr® caecal scotoma. 
Slit-lamp examination of the fundus with the Goldmann or Hruby lens gave excellent details of the discs and macular lesions. The colour of the holes varied from grey to brown and the cavity appeared to be filled to some extent with fine interlacing tissue, possibly of glial nature. This gave a veil-like appearance over the holes making the depth difficult to assess, and in Case 5 this tissue was seen to pulsate, probably a conducted impulse from the central vessels. Except in Case 8 all showed some cupping of the disc which, in Case II, was so marked as to constitute bilateral colobomata of the discs (Figs 8 and 9). This gives a clear indication of the close association between the pits and colobomata of the optic nerve head. In all cases, the overlying vitreous was intact with no abnormal vitreo-retinal connexions or posterior vitreous detachment. These latter conditions were noted by Jaffe ( 1967$)$ to produce a type of macular oedema. Even in Case 8, where vitreous traction might be thought to be a factor causing folds in the internal surface of the retina, the overlying vitreous was perfectly normal.
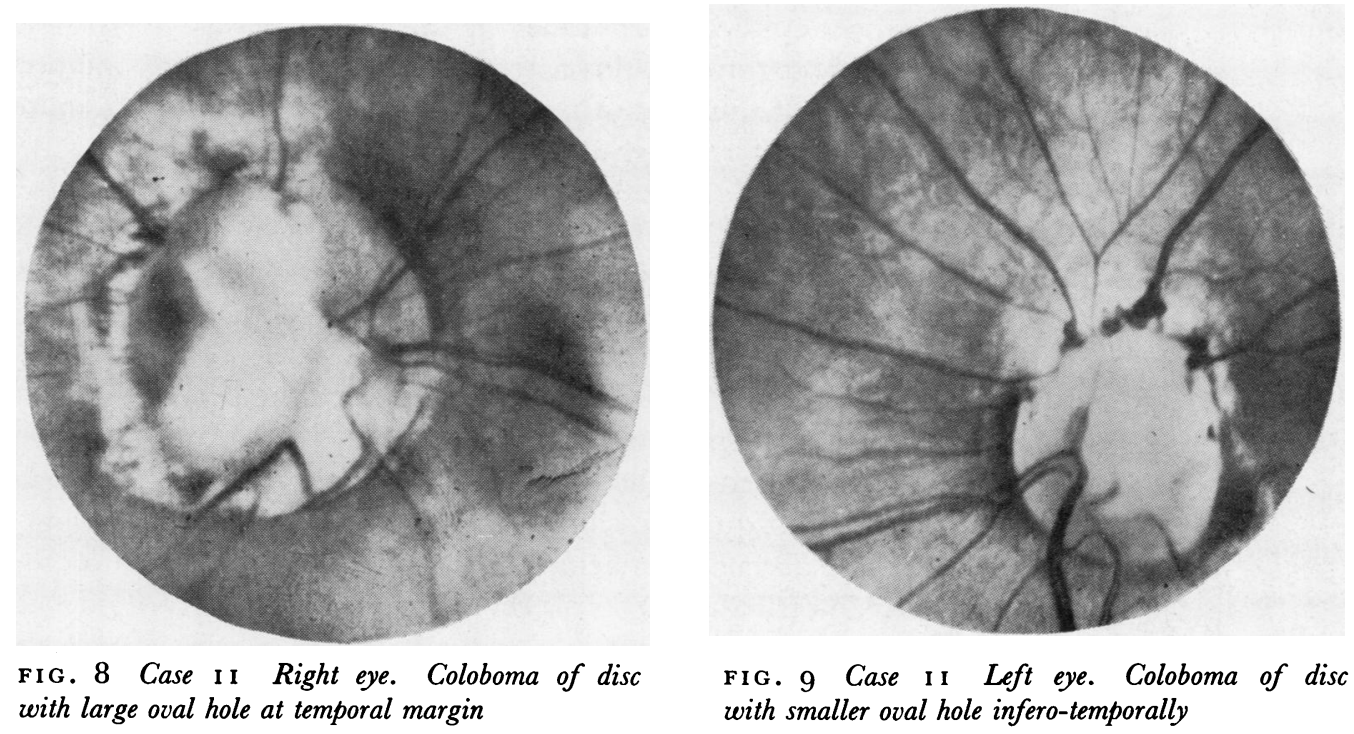

\section{Discussion}

A total of approximately 175 pits in the optic disc has now been described in the literature and macular lesions have been detected in sixty of these. The hole was always situated in a temporal position when macular changes were present. Various theories have been put forward to explain this association. Petersen (1958) stated that there was also an anomaly of the macula making it especially susceptible to disease. Kranenburg (1960) expanded on this by stating that the congenital malformation of the disc was associated with anomalous development of nerve fibre bundles and blood vessels supplying the papillo-macular region. The area of abnormal development is said to become a locus minoris resistentiae. With the passage of time, the area may develop a picture which suggests central serous retinopathy. On the other hand, Sugar considered the anomaly to be a more mechanically produced condition due to the leakage of aqueous from the vitreous chamber through the pit into the subretinal space. Zimmerman, quoted by Ferry (1963), thought that traction exerted upon the macula was probably the mechanism responsible for its ultimate detachment. Such traction might result from the lengthened 
indirect course which must be followed by ganglion cell axons arising from the part of the retina that is in relation to the pit, but also from changes in the glial tissue in the pie itself. The presence of nerve fibres in the pit could be detected by special staining methods $\underline{3}$ Anomalous development or damage to nerve fibres within the pit would explain an arcuat type of field defect. Fluorescein retinography can demonstrate several interesting features There would seem to be two different pictures. Case I showed the features of a detach ment of the retinal pigment epithelium. Case 2 suggested that oedema was in the neuro sensory retina and not deep to the pigment epithelium. Both these pictures have been described by Maumenee (1967) in cases of central serous choroidopathy. There were nom paramacular spots as occur in one type of central serous choroidopathy. In the quiescent: cases, e.g. Case 5 , the arcuate pathway from hole to macular area at the site of the previoussubretinal channel was shown. The dispersal of the pigment epithelium has resulted in $\overrightarrow{5}$ the revelation of the choroidal circulation. In Case 2, the absence of "show-through' of the choroid may be due to the relatively short duration of the oedema with minimats reaction of the pigment epithelium, but may be due to a slow turn-over rate of dye at this site, since the latest photograph in this active phase was taken at $2 \frac{1}{2}$ minutes. A brigh glow of dye within the pit was seen at 5 minutes in Case $I$ and at $2 \frac{1}{2}$ minutes in Case $2 \overrightarrow{0}$ A repeat of the fluorescein retinography $1 \frac{1}{2}$ years later in the latter, with the macula? quiescent, showed that the glow was still present at 30 minutes after the injection but hade disappeared at 60 minutes. This could indicate seepage of fluorescein from relativelk immature or poorly supported blood vessels in the hole and absorption on to glial elements $\vec{\emptyset}$ A similar leak is noticed in the neovascularization of other conditions such as diabetice retinopathy (Dollery and Oakley, I965). It may be that this transudate may track fromb the pit deep to the macula either anterior or posterior to the retinal pigment epithelium giving the two different fluorescein retinograms. Pathological studies have shown that there is little barrier between the hole and the adjoining choroido-retinal tissue, makingD access of fluid from the pit quite possible. In the later stages, when a glow of dye is still detected in the pit, the absence of macular oedema could be explained on the basis of the formation of choroido-retinal adhesions preventing the passage of fluid from the pit t㞔 the macula.

The finding of laminar flow in a retinal arteriole has not been described previously anfoㅇ. has been seen in only three cases in our $2 \frac{1}{2}$ years experience of clinical fluorescein studies: We are unable to give a satisfactory explanation for this at present.

It appears then that the acquired macular disturbance associated with pits of the opti discs is due to the leakage of fluid from the pit into the adjacent retina. This agrees witto the opinion of Sugar (1967), who thought that the fluid was likely to be aqueous whick passed from the vitreous through the pit. It is suggested, however, that alteration in the permeability of vessels in the pit could cause sufficient transudation of fluid to produce similar result.

\section{Summary}

Twelve cases, one bilateral, of pits of the optic nerve head are described; four showec. associated macular oedema and three signs of old macular disturbance. Fluoresceira retinography showed two different pictures in the active phase, and it is suggested that the source of oedema is from vessels with increased permeability within the pit and tha fluid leaks out to track deep to the macula. Laminar flow in an arteriole is described in two of the cases. 
We are grateful to the Consultants at the Glasgow Eye Infirmary, and to Doctor B. Binnie for referring patients for opinion and photography. Prof. W. S. Foulds has been a constant source of encouragement. The technical skills of Mrs. A. Currie and Mr. J. Watt and a generous grant from the W. H. Ross Foundation (Scotland) have enabled us to develop the facilities for fluorescein fundus photography at the Tennent Institute of Ophthalmology, Glasgow.

\section{References}

Calmoun, F. P. (1930) Arch. Ophthal. (Chicago), 3, 71

COATs, G. (1908) Roy. Lond. ophthal. Hosp. Rep., 17, 178

DOLLERY, C. T., and OAKLEY, N. W. (1965) Diabetes, 14, I 2 I

FERRY, A. P. (1963) Arch. Ophthal. (Chicago), 70, 346

GREEAR, J. N. (1942) Ibid., 28, 467

HAGEDOORN, A. (1928) Arch. Augenheilk., 99, 387

HENKIND, P. (1963) Amer. F. Ophthal., 55, 6 I $_{3}$

JAEnsch, P. (1931) Z. Augenheilk., 74, 162

JAFFe, N. s. (1967) Arch. Ophthal. (Chicago), 78, 585

KRANENBURG, E. W. (1960) Ibid., 64, 912

LAUBER, H. (1909) Z. Augenheilk., 21, 494

MANN, I. (1957) "Developmental Abnormalities of the Eye", 2nd ed., p. i25. B.M.A., London

MAUmenee, A. E. (1967) Arch. Ophthal. (Chicago), 78, I51

NOVOTNY, H. R., and ALVIS, D. L. (1961) Circulation, 24, 82

paufique, L., and etienne, R. (1949) Ann. Oculist. (Paris), 182, 605

PETERSEN, H. P. (1958) Acta ophthal. (Kbh.), 36, 435

REIs, w. (1908) Z. Augenheilk., 19, 505

SEEFELDER, R. (1915) v. Graefes Arch. Ophthal., 90, 129

sugar, H. s. (1962) Amer. F. Ophthal., 53, 307

$$
\begin{array}{ll}
(\text { I } 964) & \text { Ibid., 57, } 833 \\
-(1967) & \text { Ibid., 63, } 298
\end{array}
$$

Wiethe, T. (1882) Arch. Augenheilk., 11, I4

wilson, R. P. (1956) Trans. ophthal. Soc. N.Z., 8, 35 